\title{
Molecular Structure of the Hair Cell Mechanoelectrical Transduction Complex
}

\author{
Christopher L. Cunningham and Ulrich Müller \\ The Solomon Snyder Department of Neuroscience, Johns Hopkins University, Baltimore, Maryland 21205 \\ Correspondence: umuelle3@jhmi.edu; ccunni26@jhmi.edu
}

\begin{abstract}
Cochlear hair cells employ mechanically gated ion channels located in stereocilia that open in response to sound wave-induced motion of the basilar membrane, converting mechanical stimulation to graded changes in hair cell membrane potential. Membrane potential changes in hair cells cause neurotransmitter release from hair cells that initiate electrical signals in the nerve terminals of afferent fibers from spiral ganglion neurons. These signals are then propagated within the central nervous system (CNS) to mediate the sensation of hearing. Recent studies show that the mechanoelectrical transduction (MET) machinery of hair cells is formed by an ensemble of proteins. Candidate components forming the MET channel have been identified, but none alone fulfills all criteria necessary to define them as pore-forming subunits of the MET channel. We will review here recent findings on the identification and function of proteins that are components of the MET machinery in hair cells and consider remaining open questions.
\end{abstract}

M echanosensory hair cells of the mammalian cochlea are bestowed with unique structural specializations that allow them to convert sound wave-induced vibrations into electrical responses that are relayed to the central nervous system (CNS) with astonishing precision and fidelity. Each hair cell contains at its apical surface a bundle of 50-150 actin-rich stereocilia that are arranged in a staircase pattern with multiple rows of ascending heights (Fig. 1). Physical deflection of the hair bundle toward the tallest row of stereocilia leads to a depolarization of the hair cell (Gillespie and Muller 2009; Peng et al. 2011; Fettiplace and Kim 2014). Critical for mechanoelectrical transduction (MET) are the tip-link filaments that connect the stereocilia of a hair bundle along the axis of its mechanical sensitivity (Pickles et al. 1984; Assad et al. 1991; Basu et al. 2016). The tip link consists of two homodimers, one composed of two cadherin $23(\mathrm{CDH} 23)$ molecules and one of two protocadherin 15 (PCDH15) molecules, which associate in trans at their respective amino termini to connect a shorter stereocilium to its next tallest neighbor (Siemens et al. 2004; Sollner et al. 2004; Ahmed et al. 2006; Kazmierczak et al. 2007). The tip link conveys tension force to the MET channel thus leading to channel opening and an inward flow of $\mathrm{Ca}^{2+}$ and $\mathrm{K}^{+}$ ions (Fig. 1) (Fettiplace and Kim 2014).

Hair cells in the mammalian cochlea are arranged in one row of inner hair cells (IHCs) and three rows of outer hair cells (OHCs) that run along the length of the cochlear duct. Hair cells in the cochlea show a tonotopic organization where the highest frequency tones activate hair

Editors: Guy P. Richardson and Christine Petit

Additional Perspectives on Function and Dysfunction of the Cochlea available at www.perspectivesinmedicine.org

Copyright (C) 2019 Cold Spring Harbor Laboratory Press; all rights reserved; doi: 10.1101/cshperspect.a033167

Cite this article as Cold Spring Harb Perspect Med 2019;9:a033167 


\section{C.L. Cunningham and U. Müller}

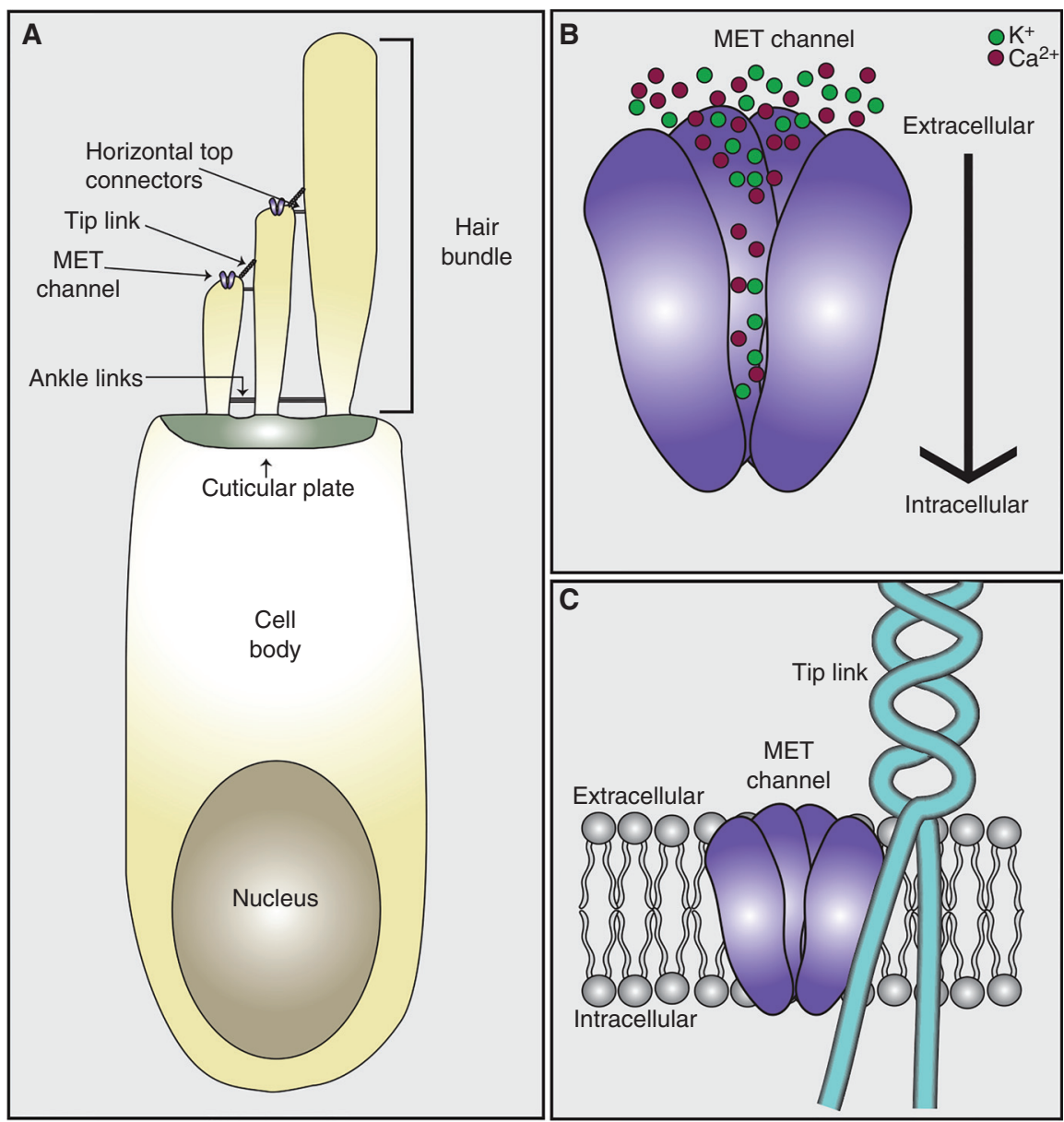

Figure 1. Cochlear hair cell anatomy. (A) Hair cells contain actin-rich stereocilia embedded in the cuticular plate at their apical surface. Stereocilia are interconnected via extracellular linkages including tip links, ankle links, and horizontal top connectors. The mechanoelectrical transduction (MET) channel that mediates auditory processing is located at the tips of shorter stereocilia at the lower end of tip links. (B) The MET channel pore is nonselective for cations with ion fluxes in hair cells composed predominantly of $\mathrm{Ca}^{2+}$ and $\mathrm{K}^{+}$. Upon normal stimulation, ions flow from the extracellular space containing endolymph into the hair cell. $(C)$ The lower end of the tip link, composed of protocadherin 15 (PCDH15), is inserted into the membrane at the tip of the stereocilia in close proximity to the MET channel pore. It is currently unknown whether the tip link binds directly to the channel pore, is connected via linker protein to the pore, or transmits force to the channel pore by impacting the local lipid environment.

cells at the base of the cochlea, the lowest tones hair cells at the apex, with a gradient in between. OHCs amplify input sound signals, whereas IHCs connect to afferent neurons and transmit sound information to the CNS (Dallos 2008; Schwander et al. 2010; Appler and Goodrich 2011; Fettiplace 2017). In rat cochlear hair cells, the conventional sensory MET channel that is critical for auditory perception is localized near the lower end of tip links in the two shorter rows of stereocilia (Beurg et al. 2009). Each hair cell has relatively few mechanotransduction channels, perhaps one to two per stereocilium (Ricci et al. 2003; Beurg et al. 2009), which show a tonotopic gradient in single-channel (unitary) conductance with increasing conductance from apex to base. This tonotopy in conductance is specific for OHCs and not IHCs (He et al. 2004; 
Beurg et al. 2006; Jia et al. 2007). There is also a gradient in $\mathrm{Ca}^{2+}$ permeability (decrease from apex to base) in OHCs, but apparently not in IHCs (Beurg et al. 2006; Kim and Fettiplace 2013).

\section{MOLECULES THAT ARE CRITICAL FOR MECHANOTRANSDUCTION}

The search for the molecules that form the sensory MET channel in mammalian hair cells and regulate its function has been going on for decades. Many candidates have been examined, but almost all failed most of the criteria defining a bona fide MET channel. Some compelling candidates that have been ruled out are TRPN1/ NOMPC (Sidi et al. 2003; Shin et al. 2005), TRPV4/VR-OAC (Liedtke et al. 2000), TRPA1 (Corey et al. 2004; Kwan et al. 2006), TRPV6, TRPM6, TRPM7 (Morgan et al. 2017), HCN1 (Ramakrishnan et al. 2009; Horwitz et al. 2010), TRPML3 (Grimm et al. 2007; Nagata et al. 2008; van Aken et al. 2008; Jors et al. 2010), PKD1 (Steigelman et al. 2011; Wu et al. 2016), PKD2 (Fettiplace 2009; Wu et al. 2016), TRPC3/TRPC6 (Quick et al. 2012; Wu et al. 2016), and TRPM1 (Gerka-Stuyt et al. 2013; $\mathrm{Wu}$ et al. 2016). However, recent studies based on the analysis of the function of genes linked to hearing loss have finally identified proteins that are integral components of the MET complex of hair cells and regulate its assembly and function. Some of these proteins are plausible candidates for the pore-forming subunits of the MET channel, whereas others affect MET via other mechanisms. We will review here current knowledge of the function of proteins that are intricately linked to MET in hair cells.

\section{Criteria for a Mechanosensitive Channel}

There are four established criteria for a candidate protein to be confirmed as a pore-forming subunit of a MET channel (Christensen and Corey 2007; Arnadottir and Chalfie 2010; Yan et al. 2013; Ranade et al. 2015). Until recently, no mammalian channels met all requirements. This changed with the discovery of the PIEZO1/ 2 proteins, which are bona fide mammalian MET channels with important functions in many cell types (Coste et al. 2010, 2012, 2015). Although PIEZO2 is expressed in hair cells, it is not essential for auditory function ( $\mathrm{Wu}$ et al. 2017) and instead carries the "reverse-polarity current" or "anomalous mechanosensitive current" that can be observed in early developing hair cells, following damage to more mature hair cells, and in hair cells from mice with mutations in several genes associated with MET function (Stepanyan and Frolenkov 2009; Alagramam et al. 2011; Kim et al. 2013; Zhao et al. 2014; Beurg et al. 2016; Wu et al. 2017). The precise function of the reverse-polarity channel is not well defined and will not be considered here.

The four established criteria for a MET channel are as follows:

1. The protein must be expressed in the proper time and place. The MET response in murine cochlear hair cells begins around postnatal day 0 (P0) in the base, and then follows in the apex 2-3 days later (Waguespack et al. 2007; Lelli et al. 2009). Thus, candidate proteins must be expressed before or concurrent with the emergence of the MET response and maintained into adulthood. Furthermore, the MET channel is localized near the lower end of tip links in proximity to the tip-link component PCDH15 (Kazmierczak et al. 2007; Beurg et al. 2009). Thus, for any protein to be considered a candidate for the MET channel, it must be expressed by P0 and localize near the lower end of tip links.

2. The protein must be required for mechanosensitivity in hair cells. Disruption of the function of the protein must affect MET in hair cells. Importantly, knockdown and knockout data need critical evaluation. Knockdown using morpholinos or short hairpin RNAs (shRNAs) has the potential for off-target artifacts and has led to incorrect conclusions regarding the mechanotransduction channel in hair cells (Corey et al. 2004; Kwan et al. 2006). Knockouts address essential functions of a protein but genetic compensation by a homolog is possible.

3. Mutations in the protein cause changes to the properties of the mechanical response. Mutations of the protein should change the prop- 
erties of the MET response. For example, mutations to critical residues in PIEZO proteins lead to changes in ion selectivity and conductance (Coste et al. 2015; Zhao et al. 2016). One needs to carefully examine the impact of all mutations and verify that the mutant protein is normally expressed and localized. Notably, trafficking/accessory/modifying functions can change properties of currents, and changes in ion selectivity and conductance are not always caused by changes to the pore. Accessory proteins (e.g., MinK modulates Kv7.1 [McCrossan and Abbott 2004]; STIM1 modulates CRAC1 [McNally et al. 2012]) and even the local lipid environment (e.g., phosphoinositol-4-5-bisphosphate [ $\left.\mathrm{PIP}_{2}\right]$ modulates MET channel properties [Borbiro et al. 2015; Effertz et al. 2017]) can impact these seemingly inherent pore properties.

4. Heterologous or ectopic expression leads to mechanical sensitivity in otherwise insensitive cells or lipid bilayers. This criterion is most critical in demonstrating that a protein is a pore-forming subunit of a mechanically sensitive ion channel. For example, PIEZO proteins confer mechanical properties upon otherwise mechanically insensitive cells, and reconstituted PIEZO proteins demonstrate channel activity in lipid bilayers (Coste et al. 2010, 2012). Recreating the correct stimulus that activates the hair cell MET channel may be challenging, as is properly expressing the pore-forming protein at the surface of cells without the full complement of trafficking partners, auxiliary subunits, and/or chaperone proteins.

In the following, we will critically evaluate the extent to which membrane proteins that have been linked to the MET channel in hair cells, namely, lipoma high mobility group IC fusion partner-like 5 (LHFPL5)/tetraspan membrane protein of hair cell stereocilia (TMHS), transmembrane inner ear (TMIE), and transmembrane channel-like proteins 1 and 2 (TMC1/2), fulfill these criteria before discussing the function of proteins without transmembrane domains (CIB2, TOMT) and lipids $\left(\mathrm{PIP}_{2}\right)$, which are also critical for MET.
Candidates for the Pore-Forming Subunit of the Mechanotransduction Channel

\section{LHFPL5/TMHS}

LHFPL5, also known as TMHS, is a protein with four predicted transmembrane domains. Mutations in LHFPL5 cause deafness in humans and mice (Longo-Guess et al. 2005; Kalay et al. 2006; Shabbir et al. 2006). LHFPL5 is a member of the tetraspan junctional complex superfamily, which includes the transmembrane $\alpha$-amino- 3 hydroxy-5-methyl-4-isoxazolepropionic acid receptor (AMPAR) regulatory proteins (TARPs) auxiliary channel subunits of glutamate receptors (Jackson and Nicoll 2011). LHFPL5 is part of a subfamily of six proteins collectively known as the LHFPL tetraspans (LHFPL1-6). LHFPL3 and LHFPL4 contribute to synaptic receptor targeting and clustering (Davenport et al. 2017; Yamasaki et al. 2017). Notably, both accessory proteins like TARPs/CACNG2/stargazin (Letts et al. 1998; Twomey et al. 2016) and pore-forming ion channel subunits like CRAC/ORAI1 (Feske et al. 2006; Prakriya et al. 2006; Vig et al. 2006) and LRRC8a/SWELL (Qiu et al. 2014; Syeda et al. 2016) have a four-transmembrane topology similar to LHFPL5 (Fig. 2).

Expressed at right place and time? Lhfpl5 messenger RNA (mRNA) is expressed in the mouse cochlea concurrent with the emergence of MET currents, and expression continues through adulthood (Xiong et al. 2012; Scheffer et al. 2015). LHFPL5 protein is localized in hair cells throughout stereocilia during the first postnatal week, with some protein concentrated at the tip-link region (Xiong et al. 2012; Mahendrasingam et al. 2017). Exogenously expressed LHFPL5 (HA-LHFPL5) also localizes to the tips of stereocilia (Xiong et al. 2012). With immunogold electron microscopy (EM) (Mahendrasingam et al. 2017), LHFPL5 protein is detected throughout developing stereocilia, but is concentrated in mature hair cells near the lower end of tip links where the MET channel is located. Consistent with the localization data, LHFPL5 binds in vitro to the tip-link component PCDH15 and to TMIE but binding to TMC1/2 has so far not been demonstrated (Xiong et al. 2012; Zhao et al. 2014; Beurg 


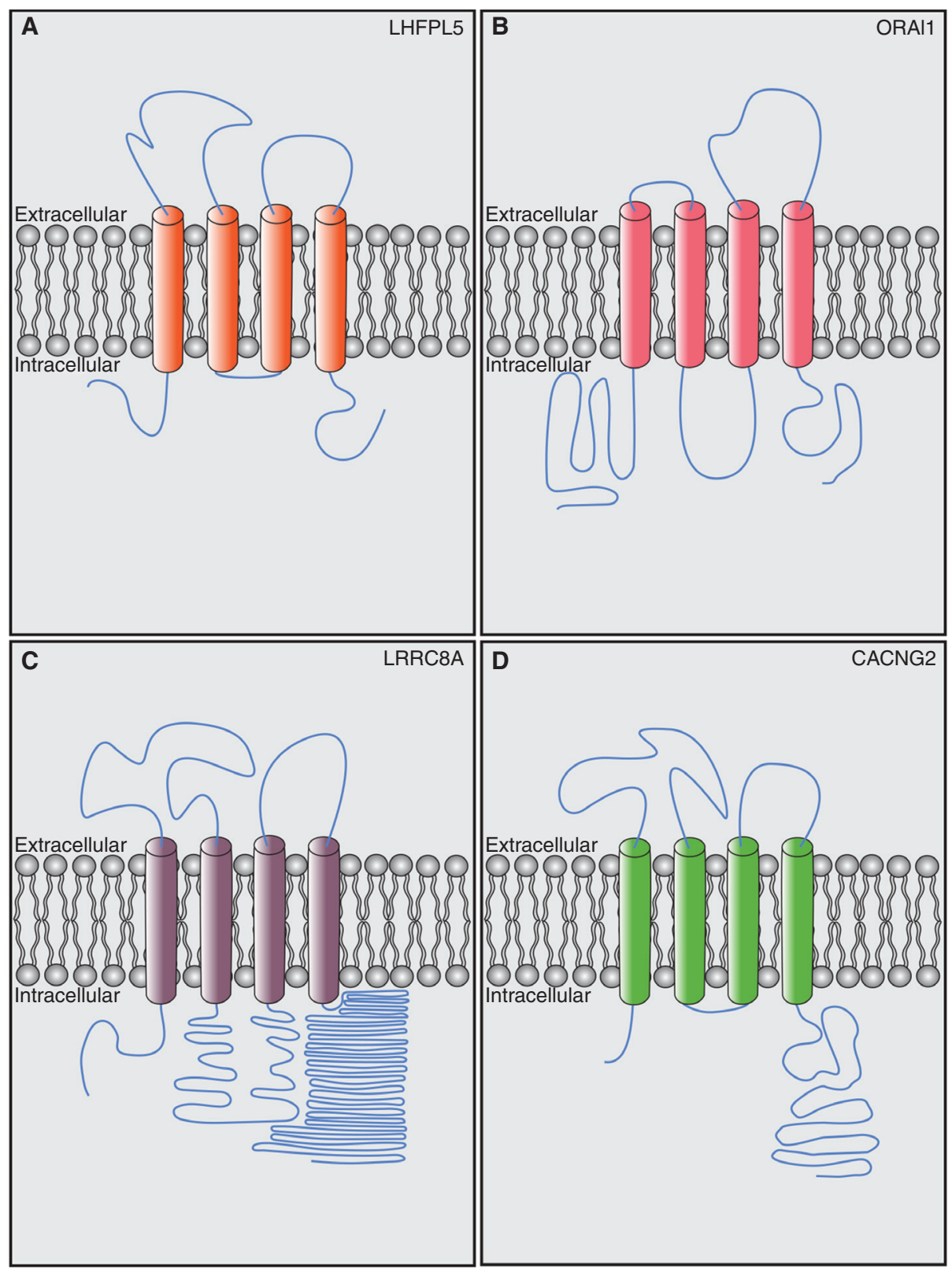

Figure 2. Proteins with predicted membrane topology similar to lipoma high mobility group IC fusion partnerlike 5 (LHFPL5). (A) LHFPL5/tetraspan membrane protein of hair cell stereocilia (TMHS) contains four predicted transmembrane domains with cytoplasmic amino- and carboxy-terminal domains. (B) ORAI1 (Prakriya et al. 2006), the pore-forming domain of the calcium-release activated calcium channel (CRAC), has a similar topology to LHFPL5. (C) LRRC8A (Qiu et al. 2014), the pore-forming subunit of the volume-regulated anion channel (VRAC), contains four transmembrane domains with cytoplasmic amino- and carboxy-terminal domains. (D) CACNG2/Stargazin (Twomey et al. 2016) is an accessory subunit of $\alpha$-amino-3-hydroxy-5-methyl-4isoxazolepropionic acid receptor (AMPAR) receptors with similar topology to LHFPL5. Lengths of domains are to relative scale. Diagrams are depicted as extracellular and intracellular at the plasma membrane, but for endoplasmic reticulum (ER) proteins, "extracellular" = ER lumen. (Figures generated based on predicted topologies from Uniprot.) 
et al. 2015b). LHFPL5 expression is higher overall in hair cells located in the low-frequency apex of the cochlea relative to the high-frequency base, but there are similar numbers of LHFPL5 puncta per stereocilial tip along the cochlear spiral (Mahendrasingam et al. 2017).

Required for mechanosensitivity? Macroscopic MET currents are decreased by $~ 90 \%$ in LHFPL5-deficient hair cells relative to wild-type (Xiong et al. 2012). Reductions in macroscopic currents are in part caused by defects in the assembly of tip links because the number of tip links are significantly reduced in LHPFL5-deficient hair cells (Xiong et al. 2012). However, the unitary conductance of MET channels in stereocilia maintaining tip links is also decreased, channel activation is slowed, and fast adaptation is impaired (Xiong et al. 2012; Beurg et al. 2015b), suggesting that LHFPL5 is intimately linked to the channel pore. The fact that current is still detected in the absence of LHFPL5 could mean that LHFPL5 does not contribute to the channel pore and rather acts like a TARP for the MET channel (Xiong et al. 2012). However, other proteins, perhaps from the LHFPL family, could partially compensate for LHFPL5 loss.

The normal tonotopic gradient in the conductance of the transducer channel is drastically reduced in Lhfpl5 mutants (Beurg et al. 2015b), suggesting that LHFPL5 is a component of the channel pore or regulates localization/function of a pore protein. Differences in LHFPL5 expression could underlie the tonotopic gradient in conductance that occurs along the cochlear spiral consistent with a possible tonotopic gradient in LHFPL5 levels (Mahendrasingam et al. 2017). Importantly, $\mathrm{TMC} 1$ is no longer present in the stereocilia of $\mathrm{Lhfpl5}^{-/-}$mutant mice, but LHFPL5 is still present in Tmc1 ${ }^{d n / d n} T m c 2^{-/-}$ mice (Beurg et al. 2015b). Thus, LHFPL5 may contribute to hair cell mechanosensitivity by regulating proper localization of TMC1. Adding weight to this hypothesis is the fact that the tonotopic gradient of MET conductance is similarly impacted in $\mathrm{Tmcl}^{-1-}$ as in $\mathrm{Lhfpl5^{-1- }}$ mice. The putative effect of LHFPL5 on TMC1 may be indirect, as coimmunoprecipitation experiments have so far not shown clear evidence for interaction in vitro (Beurg et al. 2015b).
Curiously, TMC2 localization appears not to be impacted by loss of LHFPL5, suggesting that TMC1 has unique trafficking and localization properties relative to TMC2 (Beurg et al. 2015b).

Do mutations cause changes to mechanotransduction response? Mutations in Lhfpl5 that do not impact localization to stereocilia have not been identified or tested. The hurryscurry mutation in Lhfpl5 (Longo-Guess et al. 2005; Xiong et al. 2012), which causes deafness and significant loss of MET currents, appears to affect trafficking of LHFPL5 in heterologous cells and presumably hair cells, which precludes its utility in providing insights into the role of LHFPL5 in the MET response. Other mutations linked to human deafness (Shabbir et al. 2006) do not affect binding to PCDH15 (Xiong et al. 2012), but their cell surface localization has yet to be tested.

Does heterologous or ectopic expression confer mechanosensitivity? Efficient cell-surface expression of LHFPL5 in heterologous cells is dependent upon coexpression with PCDH15 (Xiong et al. 2012). When LHFPL5 and PCDH15 are expressed in heterologous cells, mechanically evoked responses have not been successfully evoked, suggesting that LHFPL5 alone does not form a channel (Zhao et al. 2014). LHFPL5 is still present in the stereocilia of Tmc1/2 dKO mice, which suggests that LHFPL5 alone is not sufficient for the MET response in the absence of TMC1/2 (Beurg et al. 2015b).

Summary. The current working hypothesis is that LHFPL5 acts like a TARP to allosterically regulate the properties of the pore-forming subunit of the MET channel and helps in the assembly of the channel complex by regulating the transport of PCDH15 and TMC1. However, it cannot be excluded that LHFPL5 contributes directly to the pore, possibly in combination with TMC1/2 and TMIE or with yet-to-be-identified proteins.

\section{TMIE}

TMIE causes deafness in humans, mice, and zebrafish (Mitchem et al. 2002; Naz et al. 2002; Chung et al. 2007; Gleason et al. 2009). TMIE 
contains two predicted transmembrane domains with cytoplasmic amino and carboxyl termini, although it has a predicted signal sequence at the amino terminus that if cleaved would leave a single transmembrane domain with an extracellular amino terminus and intracellular carboxyl terminus (Fig. 3). It is unclear which form of the protein predominates in vivo.

Expressed at right place and time? Tmie mRNA is expressed in the mouse cochlea (Mitchem et al. 2002; Scheffer et al. 2015), and X-gal staining for LacZ expressed from the endogenous Tmie locus labels only hair cells in the cochlea (Zhao et al. 2014). Immunolocalization of TMIE with antibodies showed TMIE localized to stereocilia, with a concentration at the tips of shorter stereocilia, beginning at early postnatal stages (Zhao et al. 2014). Epitope-tagged TMIE, expressed in hair cells by injectoporation, is localized to stereocilia of hair cells as well (Zhao et al. 2014). Consistent with the localization data, TMIE interacts in vitro directly with one of three major PCDH15 isoforms (PCDH15-CD2) that are generated by alternative splicing. It binds to two additional major splice variants (PCDH15CD1, PCDH15-CD3) when in a ternary complex with LHFPL5 (Zhao et al. 2014). The temporal dynamics of TMIE expression need to be further investigated, but it seems true that TMIE is expressed in the proper time and place to contribute to MET function.

Required for mechanosensitivity? In zebrafish, mutations in Tmie cause defects in microphonic recordings indicative of MET defects (Gleason et al. 2009). MET currents are completely abolished in Tmie-null mice (Zhao et al. 2014). The MET currents cannot be rescued by exogenous expression of LHFPL 5 or TMC1/2 but can be rescued by acute expression of TMIE. The morphologies of stereocilia of Tmie ${ }^{-1-}$ mice during the time periods when MET currents were assayed are relatively normal, with no apparent loss of tip links. Interestingly, localization of LHFPL5, PCDH15-CD2, and TMC2 proteins appear normal in $\mathrm{Tmie}^{-/-}$mice, suggesting that TMIE is not primarily responsible for the transport of the transduction complex, and further implicate an integral role for TMIE in the MET channel complex (Zhao et al. 2014).
Do mutations cause changes to mechanotransduction response? The Tmie mutation in spinner $\mathrm{j}\left(s r^{j}\right)$ mice is predicted to cause a premature truncation of TMIE within the carboxyterminal cytoplasmic domain and causes profound deafness (Mitchem et al. 2002). However, it is not known whether the truncated protein is expressed and localized properly in hair cells. Several mutations in TMIE are associated with deafness in humans ( $\mathrm{Naz}$ et al. 2002). These mutations are located in the carboxy-terminal cytoplasmic tail of TMIE and affect binding to PCDH15 (Zhao et al. 2014). Full-length TMIE can completely rescue MET currents in Tmie T- $^{-1}$ hair cells, whereas some of the mutants linked to deafness localize to stereocilia but rescue transduction only partially (Zhao et al. 2014). Additional mutational analysis is necessary to further define the function of TMIE in hair cells.

Does heterologous or ectopic expression confer mechanosensitivity? Exogenous TMIE localizes to the surface of heterologous cells. However, mechanically activated currents could not be evoked with TMIE alone, or with TMIE in the presence of either LHFPL5, TMC1, TMC2, or PCDH15 (Zhao et al. 2014). Zhao et al. (2014) were able to measure PIEZO1-mediated currents in the same heterologous cells used to study MET channel components, suggesting that (1) the MET channel requires a different stimulus for activation, (2) one of the components is not localized properly (e.g., TMC1/2), or (3) the channel is not assembled properly because another factor is missing. Investigators employ stimuli including sheer stress, membrane stretch, suction stress, and mechanical indentation to stimulate mechanically sensitive channels (Ranade et al. 2015), but the most effective stimulus for the MET channel is currently unknown. Basu et al. (2016) showed that tension on the MET channel (via pulling directly on the tip link) is sufficient to open the MET channel in the absence of hair bundle deflection. This suggests that if the channel is assembled and expressed properly, an appropriate mechanical stimulus in heterologous cells should be able to open the channel.

Summary. TMIE localizes to the stereocilia, is essential for MET, and deafness-associated 


\section{C.L. Cunningham and U. Müller}
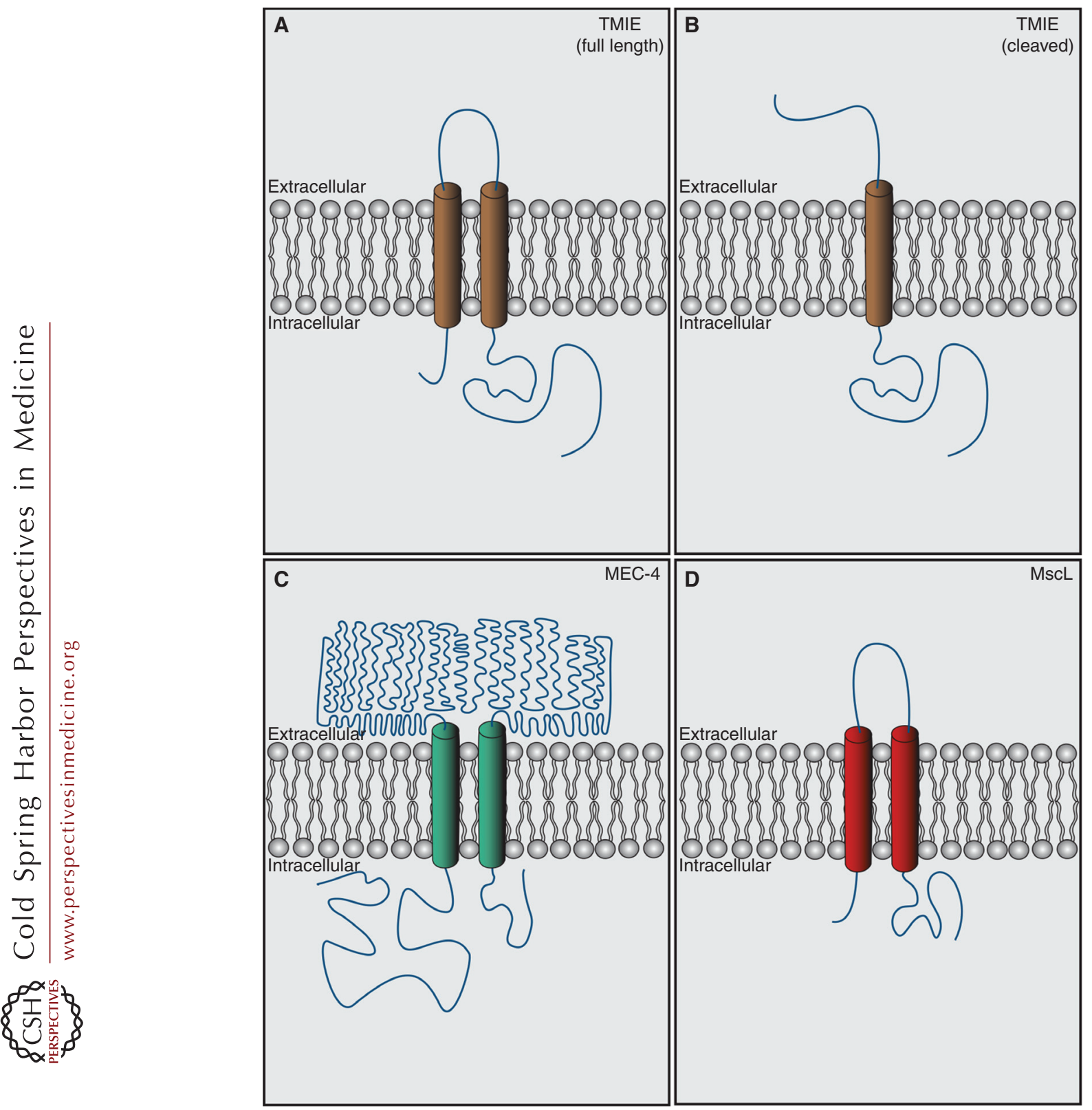

Figure 3. Proteins with predicted membrane topology similar to transmembrane inner ear (TMIE). (A) Fulllength TMIE (Zhao et al. 2014) contains two transmembrane domains with intracellular amino and carboxyl termini. (B) After cleavage of a predicted amino-terminal signal sequence, TMIE contains a single transmembrane domain with an extracellular amino terminus and an intracellular carboxyl terminus. It is unknown which version of TMIE predominates in vivo, or whether both full-length and cleaved versions are present. (C) MEC-4 (Lai et al. 1996), the pore-forming subunit of the Caenorhabditis elegans light-touch mechanosensory channel, contains two transmembrane domains with cytoplasmic amino- and carboxy-terminal domains similar to fulllength TMIE. (D) MscL (Chang et al. 1998), a mechanosensory channel expressed in prokaryotes has similar topology to full-length TMIE. Lengths of domains are to relative scale. Diagrams are depicted as extracellular and intracellular at the plasma membrane, but for endoplasmic reticulum (ER) proteins, "extracellular" = ER lumen. (Figures generated based on predicted topologies from Uniprot.) 
mutations in TMIE can affect conductance through the channel. Localizations of other known MET complex components are not affected in Tmie $e^{-/-}$animals, yet MET currents are abolished. Interestingly, the predicted topology of TMIE is similar to known mechanosensitive channel subunits, including Caenorhabditis elegans MEC-4 (ENac/DEG channel pore subunit [Lai et al. 1996; O'Hagan et al. 2005]) and MscL (the bacterial mechanosensitive channel [Chang et al. 1998]), both of which are composed of two transmembrane domains and oligomerize to form a channel pore (Fig. 3). Alternatively, TMIE, which binds PCDH15 and LHFPL5 in vitro, could link the lower end of the tip link to the channel, or properly localize an as-yet-unknown channel pore protein to the lower end of the tip link.

\section{$T M C 1 / 2$}

$\mathrm{TMC1} / 2$ are multipass transmembrane proteins. TMC1 but not TMC2 has been associated with dominant and recessive forms of deafness (Kurima et al. 2002; Vreugde et al. 2002; Kawashima et al. 2011, 2015). TMC1/2 are members of a family of eight genes (TMC1-8) that are grouped into three smaller subfamilies based on sequence similarity (Keresztes et al. 2003). TMC orthologs have been reported in Drosophila melanogaster and C. elegans (Chatzigeorgiou et al.2013; Zhang et al. 2015, 2016; Guo et al. 2016). TMC1/2 have cytoplasmic amino and carboxyl termini, six predicted transmembrane domains, and a large intracellular cytoplasmic loop between transmembrane domains 4 and 5. This topology is similar to the $\alpha$ subunit of Shaker $\mathrm{K}^{+}$channels and TRP channels (Yool and Schwarz 1991; Vannier et al. 1998; Long et al. 2005; Labay et al. 2010), but is also similar to transporter proteins with intracellular functions like ZnT-1 (Fig. 4) (Palmiter and Huang 2004). It is still unknown whether TMC proteins are ion channels. The large intracellular domain between TM4 and 5 of TMC1 is the site of the $d n$ mutation in mice, and some alternative topologies suggest that this region has two additional transmembrane domains that could act as a reentrant loop for a potential pore (Labay et al. 2010; Fettiplace 2016).
TMC proteins have a variety of functions in different species and tissues but the relationship to MET is unclear for most TMCs. TMC in C. elegans was initially reported to be essential for salt sensation, but this was not confirmed (Chatzigeorgiou et al. 2013; Wang et al. 2016). Research by the Garcia Laboratory suggests a developmental function for C. elegans TMC1 with little indication for a role in sensory transduction (Zhang et al. 2015), and Wang and colleagues (2016) have demonstrated that TMC1 in worms is critical for alkaline sensation. Intriguingly, Yue et al. (2018) linked C. elegans TMC proteins to egg laying and showed that manipulating TMC expression could modulate resting membrane potential via a depolarizing background leak conductance. Furthermore, expression of mammalian TMC1/2 rescued defects in worms deficient for C. elegans TMC proteins (Yue et al. 2018). Additional disparate functions have been attributed to the TMC ortholog in Drosophila. Fruit flies with mutations in $t m c$ have defects in larval locomotion that could be rescued by mammalian TMC1/2 (Guo et al. 2016), and impaired food texture discrimination facilitated by a putative mechanical stimulus (Zhang et al. 2016). However, mechanically sensitive currents could not be evoked in S2 cells expressing Drosophila TMC (Guo et al. 2016). In humans, mutations in TMC6/EVER1 and TMC8/EVER2 are linked to epidermodysplasia verruciformis (Ramoz et al. 2002) and TMC6/8 regulate cellular zinc distribution in concert with the zinc transporter ZnT-1 (Lazarczyk et al. 2008).

Expressed at right place and time? Tmc1 and Tmc 2 mRNA are expressed in hair cells. Quantitative polymerase chain reaction (PCR) experiments show that Tmc2 mRNA is expressed first, starting around the onset of MET sensitivity at birth and then maintained until P10, when it stops being expressed. Tmc1 mRNA starts to be detected around P3, with levels subsequently increasing, and is maintained into adulthood (Kawashima et al. 2011).

Using immunolocalization, TMC1 protein was detected in stereocilia and kinocilia as early as P5 (Beurg et al. 2015b). Kurima and colleagues (2015) used bacterial artificial chromo- 


\section{C.L. Cunningham and U. Müller}

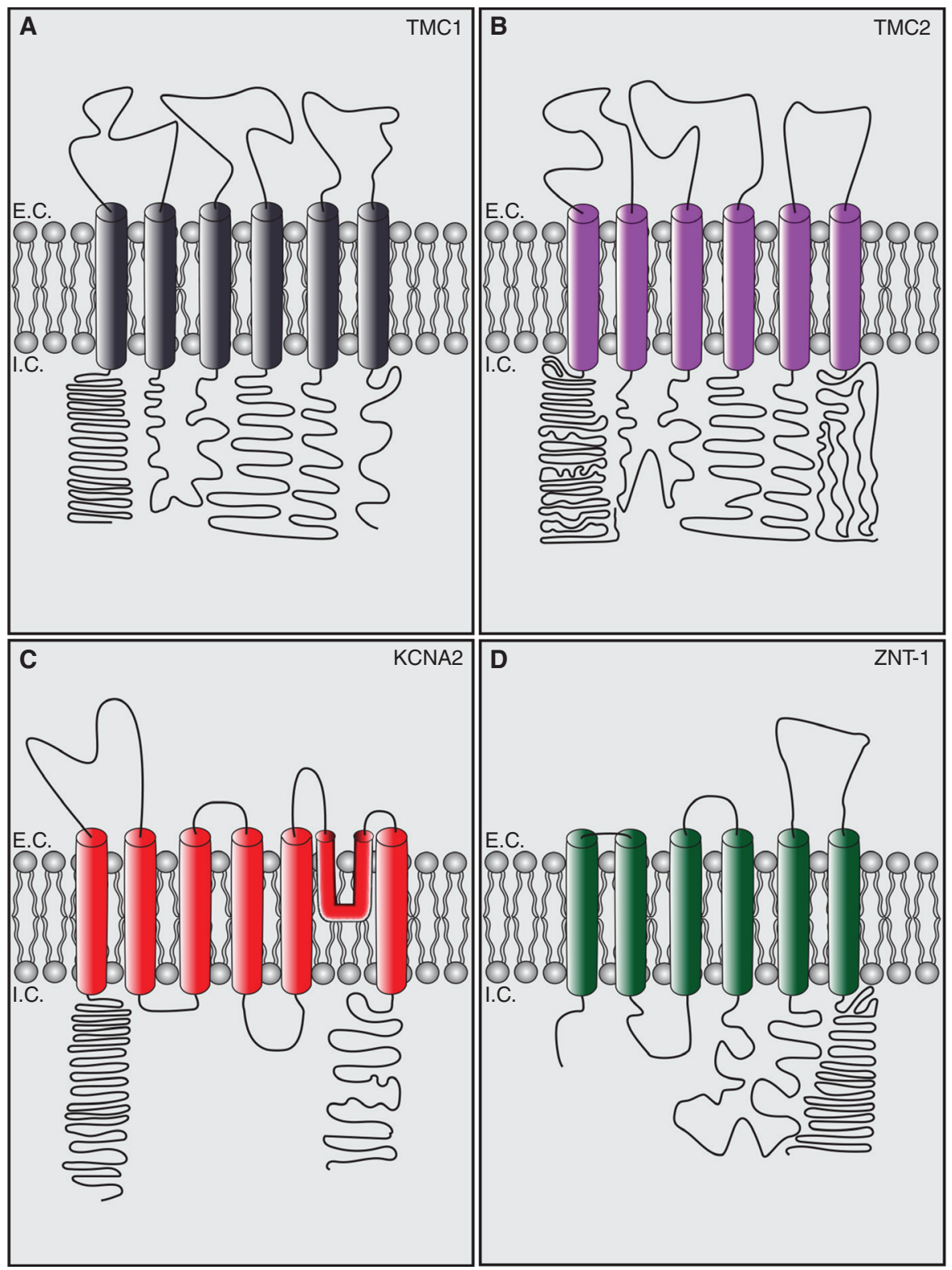

Figure 4. Proteins with predicted membrane topology similar to transmembrane channel-like proteins 1 and 2 (TMC1/2). (A) Full-length TMC1 (Labay et al. 2010) contains six predicted transmembrane domains with intracellular amino and carboxyl termini. (B) Full-length TMC2 (Kurima et al. 2003) contains six predicted transmembrane domains with intracellular amino and carboxyl termini. (C) KCNA1 (Long et al. 2005), the poreforming subunit of the Shaker $\mathrm{K}^{+}$channel Kv1.2, contains six transmembrane domains, a membrane reentrant loop forming the pore between TM5 and TM6 and cytoplasmic amino- and carboxy-terminal domains. Some alternate topologies for TMC1/2 predict a possible pore reentrant loop between TM4 and TM5 (Labay et al. 2010). (D) ZnT-1 (Palmiter and Huang 2004), a zinc transporter that regulates transport of zinc between the endoplasmic reticulum (ER) and the cytoplasm, has a similar predicted topology to TMC1/2. Lengths of domains are to relative scale. Diagrams are depicted as extracellular and intracellular at the plasma membrane, but for ER proteins, "extracellular" = ER lumen. E.C., extracellular; I.C., intracellular. (Figures generated based on predicted topologies from Uniprot.) 
some (BAC) transgenic techniques to generate TMC1-mCherry and TMC2-AcGFP mice. These mice showed expression of the transgenes with a similar temporal pattern as for TMC1 and TMC2 mRNAs. TMC1-mCherry and TMC2AcGFP localized to tips of stereocilia and appeared to be at higher levels in shorter stereocilia. There was some colocalization of TMC1mCherry and TMC2-AcGFP, although a significant number of puncta were not colocalized. TMC1-mCherry was also expressed in the cell body of hair cells and Kurima and colleagues (2015) used antibodies to demonstrate immunolabeling for TMC1 and TMC2 at the tips of stereocilia. Overexpressed epitope-tagged TMC1/2 also localizes to stereocilia (Kawashima et al. 2011; Zhao et al. 2014; Beurg et al. 2015b; Cunningham et al. 2017). Consistent with the localization data, TMC1/2 interact with PCDH15, but not LHFPL5 and TMIE when expressed in heterologous cells (Maeda et al. 2014; Beurg et al. 2015b). TMC1/2 in heterologous cells remain in the ER, suggesting that these interactions occur in an intracellular compartment.

Required for mechanosensitivity? Initially, it was reported that the deafness-causing mutations in Tmc1 in mice (Bth and $d n$ ) affect maturation and survival of hair cells because the cells do not acquire mature potassium currents (Marcotti et al. 2006). Later studies demonstrated that MET current properties in these mutants were also affected, along with substantial residual current being carried by TMC2 transiently during the first few postnatal days. Double mutants of $T m c 1^{d n / d n} ; T m c 2^{-1-}$ and $T m c 1^{-/-}$; Tmc2 ${ }^{-1-}$ (Kawashima et al. 2011) completely lack MET current without loss of tip links (Kawashima et al. 2011; Kim et al. 2013). By P9-P10, when TMC2 expression is down-regulated in the cochlea, MET currents in Tmc1 ${ }^{d n / d n}$ single mutants dramatically decrease and eventually are lost, suggesting that at later stages, TMC1 alone is essential for the MET current (Kim and Fettiplace 2013). TMC1 and TMC2, when overexpressed individually from viral vectors, can partially rescue MET function in $\mathrm{Tmcl}^{-/-}$; Tmc $2^{-1-}$ hair cells (Kawashima et al. 2011; Askew et al. 2015). Overexpression of the amino terminus of zebrafish TMC2a can act as a dom- inant negative and decreases the MET response in wild-type zebrafish hair cells (Maeda et al. 2014). This manipulation altered the localization of PCDH15, which suggests that TMC proteins may play a role in linking the tip link to the channel if they do not compose the channel themselves.

Do mutations cause changes to mechanotransduction response? MET currents in hair cells expressing TMC1 or TMC2 alone have different properties from those expressing both TMC1 and TMC2 (Kim and Fettiplace 2013; Pan et al. 2013; Corns et al. 2017). TMC1-only expressing hair cells have lower unitary conductances and lower $\mathrm{Ca}^{2+}$ permeabilities, whereas TMC2-only expressing hair cells have higher unitary conductances and higher $\mathrm{Ca}^{2+}$ permeabilities. TMC2 also confers a reduced affinity of the MET channel to the permeant blocker dihydrostreptomycin, similar to the TMC1 Bth mutation (see below) (Corns et al. 2017). It has been proposed that TMC1 and TMC2 coassemble into channels thus leading to the tonotopic gradient in single-channel (unitary) conductance and $\mathrm{Ca}^{2+}$ permeability in wild-type hair cells (Kim and Fettiplace 2013). This is unlikely because TMC2 is not expressed later than P10, and TMC1 and TMC2 do not exhibit notable colocalization in hair cells (Kurima et al. 2015).

Additionally, fast adaptation properties are distinct in TMC2-expressing IHCs relative to TMC1-expressing IHCs (Pan et al. 2013), similar to that observed in $L h f p l 5^{-1-}$ animals (Xiong et al. 2012). If LHFPL5 is responsible for TMC1 (but not TMC2) localization to stereocilia and thus the residual current in Lhfpl5-null animals is carried by TMC2 (Beurg et al. 2015b), then perhaps the effects on adaptation in TMC2-only hair cells (Tmc1-null) and Lhfpl5 $5^{-1-}$ hair cells is the result of a loss of TMC1.

Mutations in Tmcl ( $d n$ and Bth) cause changes to the MET response (Kim and Fettiplace 2013; Pan et al. 2013; Beurg et al. 2015a; Corns et al. 2016). However, it is currently unclear whether the mutations affect protein localization. The $d n$ mutation is caused by an inframe deletion of amino acids 463-519, located in the long internal cytoplasmic loop (Kurima et al. 2002). The eventual complete loss of MET 
current in the $d n$ mutants after the down-regulation of TMC2 at P9-10 suggests that localization or expression of the mutant protein may be affected (Kim and Fettiplace 2013). The Bth mutation $(\mathrm{M} 412 \mathrm{~K})$ adds a positive charge in a predicted extracellular loop between TM domain 3 and 4 (Vreugde et al. 2002) and alters properties of the MET current (Pan et al. 2013; Beurg et al. 2015a; Corns et al. 2016) with a decrease in unitary conductance and $\mathrm{Ca}^{2+}$ permeability of IHCs (Pan et al. 2013) and OHCs (Corns et al. 2016), although it was also reported that only $\mathrm{Ca}^{2+}$ permeability is affected (Beurg et al. 2015a). Pan et al. 2013 reported an increase in a $\mathrm{Ca}^{2+}$-dependent block in IHCs from Bth mice, whereas Corns et al. 2016 reported a decreased sensitivity of the MET channel to block by the permeant blocker dihydrostreptomycin in Bth OHCs (Pan et al. 2013; Corns et al. 2016). These data hint at the possibility that $\mathrm{TMC} 1 / 2$ form the MET channel pore. However, these changes in ion selectivity could be caused by mutations in accessory proteins as has been reported for other ion channel complexes (e.g., MinK or Stim1 [Goldstein and Miller 1991; McNally et al. 2012]). Furthermore, changes to the local lipid environment (Effertz et al. 2017) lead to similar changes in conductance and $\mathrm{Ca}^{2+}$-selectivity of the MET channel in hair cells and in effects of blockers as reported for TMC1 mutations. There are other mouse mutants of Tmcl that cause profound deafness (Manji et al. 2012) - Baringo (Y182C), Nice (Y449A), and Stitch (Y554L), but their effects on MET have not been studied.

Does heterologous or ectopic expression confer mechanosensitivity? Heterologously expressed TMC proteins localize to the ER, even in the presence of other MET-associated proteins (Labay et al. 2010; Sirianant et al. 2014; Zhao et al. 2014; Cunningham et al. 2017; Giese et al. 2017), and no reports show mechanosensitive currents in TMC-expressing cells, although many laboratories have tried (Labay et al. 2010; Kawashima et al. 2011; Zhao et al. 2014; Guo et al. 2016). Perhaps a chaperone or trafficking partner for $\mathrm{TMC} 1 / 2$ is missing in heterologous cells, because $\mathrm{TMC1} / 2$ go to stereocilia in hair cells (Kurima et al. 2015). However, other TMC proteins localize to the ER and have reported functions there (Lazarczyk et al. 2008; Sirianant et al. 2014).

Summary. TMC1/2 proteins are clearly components of the MET channel complex in hair cells but they have several possible specific roles: (1) TMC1/2 alone or together with other proteins (i.e., LHFPL5 or TMIE) form a channel pore; (2) TMC1/2 make up an external vestibule of the channel that regulates conductance and selectivity similar to the Slo $\mathrm{Ca}^{2+}$-activated $\mathrm{K}^{+}$ channel (Brelidze et al. 2003; Beurg et al. 2014); (3) TMC1/2 are auxiliary subunits responsible for proper localization of the channel pore; or (4) TMC1/2 link the tip link to the channel pore. Heterologous expression and structural studies will be crucial to distinguish between these possibilities.

\section{Additional Molecules Critical for the Mechanosensitive Response in Cochlear Hair Cells}

Additional molecules have been identified that affect MET in hair cells, although they are not similar in structure to ion channels, and thus unlikely to contribute to the pore of the MET channel. CDH23 and PCDH15 comprise the tip link and are critical for transmitting force onto the MET channel either directly or indirectly via linker proteins or the local lipid membrane (Siemens et al. 2004; Sollner et al. 2004; Ahmed et al. 2006; Kazmierczak et al. 2007). MYO7A, HARMONIN, and SANS are present at the upper end of the tip link and might regulate transduction via effects on the tip-link protein or by regulating hair bundle stiffness (Fig. 5) (Holt et al. 2002; Kros et al. 2002; Adato et al. 2005; Grillet et al. 2009; Michalski et al. 2009; Grati and Kachar 2011). Others such as WHIRLIN, MYOXVa, and CLRN1 have roles in hair bundle development and might affect MET secondarily (Fig. 5) (Delprat et al. 2005; Ahmed et al. 2006; Stepanyan and Frolenkov 2009; Geng et al. 2012; Xiong et al. 2012). A direct link to the transduction machinery is likely for CIB2 and TOMT, as well as for $\mathrm{PIP}_{2}$, a phospholipid component of the stereociliary membrane (Fig. 5), and these molecules will be discussed here further. 


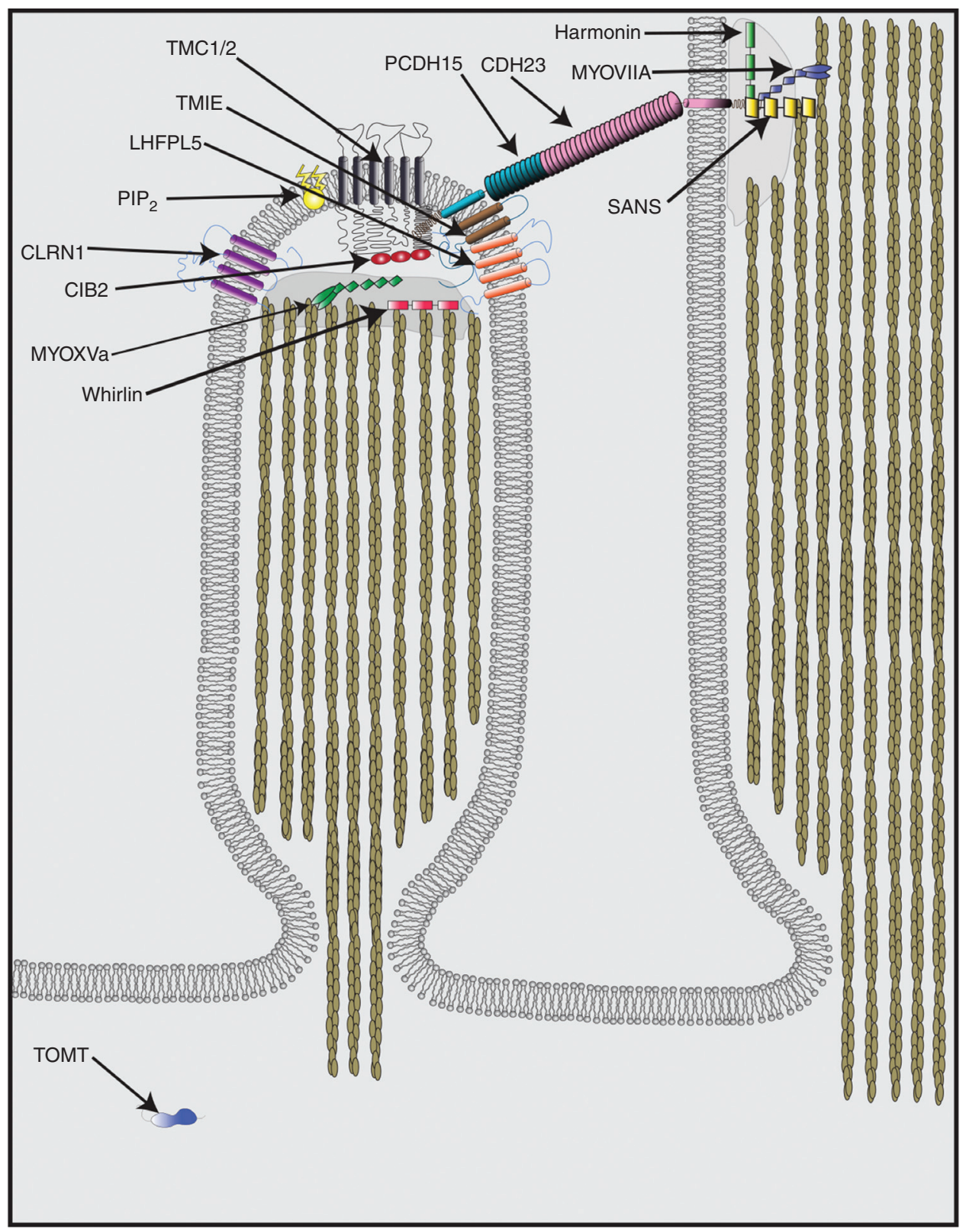

Figure 5. Molecules that contribute to mechanoelectrical transduction (MET) in cochlear hair cells. CDH23 and PCDH15 interact to form the tip link, which connects the tip of shorter row stereocilia to the side of taller row stereocilia. Harmonin, SANS, and MYOVIIA all localize to the upper tip-link density and interact in a complex with CDH23 to regulate MET and tip-link tension. LHFPL5, TMIE, and TMC1/2 all localize to the tips of stereocilia at the lower end of the tip link and are essential for MET function. PIP $_{2}$ and CIB2 localize to the tips of stereocilia and directly contribute to MET function. CLRN1, MYOXVa, and Whirlin localize to the tips of stereocilia and impact MET function, but these effects may be secondary to their effects on stereocilia morphology. TOMT localizes exclusively to the cell body but is essential for MET function by regulating TMC1/2 localization to stereocilia. 


\section{CIB2}

Mutations in calcium and integrin-binding family member 2 (CIB2) cause deafness (Riazuddin et al. 2012). CIB2 is a member of a family of proteins (CIB1-4) containing EF hand domains (Gentry et al. 2005), which are thought to mediate intracellular $\mathrm{Ca}^{2+}$ signaling. CIB2 contains no transmembrane domains but contains three EF-hand domains, of which the second and third bind $\mathrm{Ca}^{2+}$ (Blazejczyk et al. 2009). CIB2 interacts in vitro with WHIRLIN, MYO7A, TMC1, and TMC2, but not LHFPL5 or TMIE (Riazuddin et al. 2012; Giese et al. 2017). Several deafness-associated mutations weaken the interactions with TMC1/2 (Giese et al. 2017).

CIB2 is expressed in the stereocilia of hair cells (Riazuddin et al. 2012; Giese et al. 2017; Michel et al. 2017; Wang et al. 2017) and both a null mutation and a point mutation that are linked to disease in humans (F91S) abolish MET (Giese et al. 2017; Michel et al. 2017; Wang et al. 2017). MYO7A, HARMONIN, PCDH15, TMC1, and TMC2 appear to localize properly in Cib2 mutants (Giese et al. 2017), suggesting that CIB2 does not play a role in the transport of the MET complex. In heterologous cells, CIB2 is localized in intracellular compartments and is not sufficient to transport TMC1/2 to the cell surface (Giese et al. 2017).

Hair bundle morphology is altered in Cib2 mutants, especially after the first postnatal week. However, the morphology was relatively normal during the time when MET was assayed, suggesting that the morphological defects are not causative for the MET defects (Giese et al. 2017; Michel et al. 2017). Although it is clear that CIB2 is essential for mechanotransduction, its precise role merits further study.

\section{TOMT/LRTOMT2/COMT2}

Mutations in transmembrane O-methyltransferase (TOMT, also known as COMT2 or LRTOMT in humans) cause deafness in zebrafish, mice, and humans (Ahmed et al. 2008; Du et al. 2008; Erickson et al. 2017). The gene in humans (LRTOMT) is a fusion gene that contains two alternate reading frames, encoding the proteins LRTOMT1 and LRTOMT2 (Ahmed et al. 2008). LRTOMT2 is homologous to TOMT, which is a protein conserved from zebrafish to humans that is similar in sequence to catechol-O-methyltransferase (COMT). COMT regulates catecholamine levels in the brain and periphery (Mannisto and Kaakkola 1999) by enzymatic activity of its methyltransferase domain. TOMT has residual methyltransferase activity in vitro (Du et al. 2008). The human protein (LRTOMT2) contains a single transmembrane domain (Ahmed et al. 2008), and the zebrafish protein (TOMT) is predicted to have a single transmembrane domain (Erickson et al. 2017), but most analysis programs suggest that mouse TOMT has no transmembrane domain (Cunningham et al. 2017).

Tomt mRNA is expressed in hair cells (Ahmed et al. 2008; Du et al. 2008; Erickson et al. 2017) and epitope-tagged TOMT localizes exclusively to the cell body of hair cells. The pattern appears relatively diffuse throughout the cell body of zebrafish and mouse hair cells and may be enriched in the Golgi apparatus of zebrafish (Cunningham et al. 2017; Erickson et al. 2017). Immunolocalization with an antibody to TOMT showed expression in the cytoplasm of hair cells (Ahmed et al. 2008). In heterologous cells TOMT also localizes to the ER and can interact with PCDH15, TMIE, TMHS, and TMC1/2 (Cunningham et al. 2017; Erickson et al. 2017).

MET currents are abolished in zebrafish and mouse Tomt mutants (Cunningham et al. 2017; Erickson et al. 2017) and the defect can be rescued at least partially by the expression of TOMT mutants devoid of methyltransferase activity, suggesting that TOMT contributes to MET independent of its enzymatic function (Cunningham et al. 2017; Erickson et al. 2017). Hair bundle morphology (Cunningham et al. 2017; Erickson et al. 2017) was relatively normal during the period in which MET currents were measured, and tip-link numbers are normal in IHCs and OHCs from Tomt mutant mice (Cunningham et al. 2017). However, TMC1/2 are no longer localized properly to stereocilia in zebrafish or mice, suggesting a transport or assembly function for TOMT (Cunningham et al. 2017; 
Erickson et al. 2017). In heterologous cells, TOMT alone is not sufficient to target TMC1/ 2 to the cell membrane (Cunningham et al. 2017; Erickson et al. 2017). Thus, TOMT likely works in concert with other unidentified proteins in protein transport. The function of TOMT is perhaps similar to that of MEC-6 and POML-1 in regulating proper surface localization of MEC-4, the mechanosensitive channel in C. elegans that is critical for gentle touch (Arnadottir and Chalfie 2010; Chen et al. 2016).

$\mathrm{PIP}_{2}$

$\mathrm{PIP}_{2}$ is a phospholipid component of cell membranes that can alter ion channel function (Hardie and Franze 2012; Zhang et al. 2013; Borbiro et al. 2015). PIP 2 has been localized to the stereocilia of frog (Hirono et al. 2004), mouse (Goodyear et al. 2008), and rat hair cells (Effertz et al. 2017). Depleting PIP $_{2}$ pharmacologically from hair bundles reduces adaptation in bullfrog saccular hair cells and decreases the MET current (Hirono et al. 2004). In hair cells from the rat cochlea, $\mathrm{PIP}_{2}$ depletion leads to surprising changes in MET function, including loss of fast adaptation, decreases in MET single-channel conductance, changes in ion selectivity, slower activation of the channel, an increase in the open probability at rest, and a decrease in the $\mathrm{Ca}^{2+}$ pore block (Effertz et al. 2017). Considering the fact that $\mathrm{PIP}_{2}$ is a component of the local cell membrane, these data reinforce the fact that seemingly inherent properties of the channel such as single-channel conductance and ion selectivity can be modulated by factors not inherent to the channel pore. Interestingly, $\mathrm{PIP}_{2}$ modulation also affects PIEZO channel activity (Borbiro et al. 2015).

\section{CONCLUSION}

Recent years have seen significant progress in the identification of core components of the mechanotransduction machinery of hair cells with the identification of the proteins that form tip links and proteins that are intricately linked to the function of the MET channel (Fig. 5), either by contributing to the channel complex directly or by regulation of assembly and function of the MET complex. Several integral membrane proteins have been identified (LHFPL5, TMIE, $\mathrm{TMC1} / 2$ ) that are candidates to contribute to the pore of the MET channel or to regulate the function of pore-forming subunits. The specific function of these proteins still needs to be defined. Intriguingly, seemingly intrinsic properties of the channel pore (i.e., channel conductance, ion selectivity, and channel block) can be impacted by modifying the lipid environment (i.e., $\mathrm{PIP}_{2}$ ) surrounding the channel. It is thus imperative to develop a heterologous system to study the mechanisms that regulate MET channel assembly and the function. A major stumbling block is the fact that TMC proteins in heterologous cells remain in the ER. Interestingly, some members of the TMC family even appear to be resident ER proteins (Lazarczyk et al. 2008; Sirianant et al. 2014). Perhaps the MET channel is similar to VRAC channels, which are heteromeric channel complexes composed of SWELL1/LRRC8A and up to four additional LRRC8 subunits (LRRC8B-E) that regulate cell volume (Qiu et al. 2014; Voss et al. 2014; Syeda et al. 2016). Possibly relevant is the fact that VRAC subunit composition can differ and different subunit combinations confer distinct variations of channel properties (Syeda et al. 2016). A heteromeric channel complex could explain tonotopic differences in the properties of the MET channel, a feature of the channel that may be critical for our ability to encode sound of different frequencies to provide our sense of hearing.

\section{ACKNOWLEDGMENTS}

This work is supported by funding from the National Institutes of Health (NIH) (U.M., DC005965, DC014713, DC014427, DC016960; C.L.C., DC015724). U.M. is a Bloomberg Distinguished Professor.

\section{REFERENCES}

Adato A, Michel V, Kikkawa Y, Reiners J, Alagramam KN, Weil D, Yonekawa H, Wolfrum U, El-Amraoui A, Petit C. 
C.L. Cunningham and U. Müller

2005. Interactions in the network of Usher syndrome type 1 proteins. Hum Mol Genet 14: 347-356.

Ahmed ZM, Goodyear R, Riazuddin S, Lagziel A, Legan PK, Behra M, Burgess SM, Lilley KS, Wilcox ER, Riazuddin S, et al. 2006. The tip-link antigen, a protein associated with the transduction complex of sensory hair cells, is protocadherin-15. J Neurosci 26: 7022-7034.

Ahmed ZM, Masmoudi S, Kalay E, Belyantseva IA, Mosrati MA, Collin RW, Riazuddin S, Hmani-Aifa M, Venselaar H, Kawar MN, et al. 2008. Mutations of LRTOMT, a fusion gene with alternative reading frames, cause nonsyndromic deafness in humans. Nat Genet 40: 13351340.

Alagramam KN, Goodyear RJ, Geng R, Furness DN, van Aken AF, Marcotti W, Kros CJ, Richardson GP. 2011. Mutations in protocadherin 15 and cadherin 23 affect tip links and mechanotransduction in mammalian sensory hair cells. PLoS ONE 6: e19183.

Appler JM, Goodrich LV. 2011. Connecting the ear to the brain: Molecular mechanisms of auditory circuit assembly. Prog Neurobiol 93: 488-508.

Arnadottir J, Chalfie M. 2010. Eukaryotic mechanosensitive channels. Annu Rev Biophys 39: 111-137.

Askew C, Rochat C, Pan B, Asai Y, Ahmed H, Child E, Schneider BL, Aebischer P, Holt JR. 2015. Tmc gene therapy restores auditory function in deaf mice. Sci Transl Med 7: 295ra108.

Assad JA, Shepherd GM, Corey DP. 1991. Tip-link integrity and mechanical transduction in vertebrate hair cells. Neuron 7: 985-994.

Basu A, Lagier S, Vologodskaia M, Fabella BA, Hudspeth AJ. 2016. Direct mechanical stimulation of tip links in hair cells through DNA tethers. eLife 5: 16041.

Beurg M, Evans MG, Hackney CM, Fettiplace R. 2006. A large-conductance calcium-selective mechanotransducer channel in mammalian cochlear hair cells. J Neurosci 26: 10992-11000.

Beurg M, Fettiplace R, Nam JH, Ricci AJ. 2009. Localization of inner hair cell mechanotransducer channels using high-speed calcium imaging. Nat Neurosci 12: 553-558.

Beurg M, Kim KX, Fettiplace R. 2014. Conductance and block of hair-cell mechanotransducer channels in transmembrane channel-like protein mutants. J Gen Physiol 144: 55-69.

Beurg M, Goldring AC, Fettiplace R. 2015a. The effects of Tmcl Beethoven mutation on mechanotransducer channel function in cochlear hair cells. J Gen Physiol 146: 233243.

Beurg M, Xiong W, Zhao B, Muller U, Fettiplace R. 2015b. Subunit determination of the conductance of hair-cell mechanotransducer channels. Proc Natl Acad Sci 112: 1589-1594.

Beurg M, Goldring AC, Ricci AJ, Fettiplace R. 2016. Development and localization of reverse-polarity mechanotransducer channels in cochlear hair cells. Proc Natl Acad Sci 113: 6767-6772.

Blazejczyk M, Sobczak A, Debowska K, Wisniewska MB, Kirilenko A, Pikula S, Jaworski J, Kuznicki J, Wojda U. 2009. Biochemical characterization and expression analysis of a novel $\mathrm{EF}$-hand $\mathrm{Ca}^{2+}$ binding protein calmyrin2 (Cib2) in brain indicates its function in NMDA receptor mediated $\mathrm{Ca}^{2+}$ signaling. Arch Biochem Biophys 487: 6678.

Borbiro I, Badheka D, Rohacs T. 2015. Activation of TRPV1 channels inhibits mechanosensitive Piezo channel activity by depleting membrane phosphoinositides. Sci Signal 8: ra15.

Brelidze TI, Niu X, Magleby KL. 2003. A ring of eight conserved negatively charged amino acids doubles the conductance of BK channels and prevents inward rectification. Proc Natl Acad Sci 100: 9017-9022.

Chang G, Spencer RH, Lee AT, Barclay MT, Rees DC. 1998. Structure of the MscL homolog from Mycobacterium tuberculosis: A gated mechanosensitive ion channel. Science 282: 2220-2226.

Chatzigeorgiou M, Bang S, Hwang SW, Schafer WR. 2013. tmc-1 encodes a sodium-sensitive channel required for salt chemosensation in C. elegans. Nature 494: 95-99.

Chen Y, Bharill S, Altun Z, O'Hagan R, Coblitz B, Isacoff EY, Chalfie M. 2016. Caenorhabditis elegans paraoxonase-like proteins control the functional expression of $\mathrm{DEG} / \mathrm{ENaC}$ mechanosensory proteins. Mol Biol Cell 27: 1272-1285.

Christensen AP, Corey DP. 2007. TRP channels in mechanosensation: Direct or indirect activation? Nat Rev Neurosci 8: 510-521.

Chung WH, Kim KR, Cho YS, Cho DY, Woo JH, Ryoo ZY, Cho KI, Hong SH. 2007. Cochlear pathology of the circling mouse: A new mouse model of DFNB6. Acta Otolaryngol 127: 244-251.

Corey DP, Garcia-Anoveros J, Holt JR, Kwan KY, Lin SY, Vollrath MA, Amalfitano A, Cheung EL, Derfler BH, Duggan A, et al. 2004. TRPA1 is a candidate for the mechanosensitive transduction channel of vertebrate hair cells. Nature 432: 723-730.

Corns LF, Johnson SL, Kros CJ, Marcotti W. 2016. Tmc1 point mutation affects $\mathrm{Ca}^{2+}$ sensitivity and block by dihydrostreptomycin of the mechanoelectrical transducer current of mouse outer hair cells. J Neurosci 36: 336-349.

Corns LF, Jeng JY, Richardson GP, Kros CJ, Marcotti W. 2017. TMC2 modifies permeation properties of the mechanoelectrical transducer channel in early postnatal mouse cochlear outer hair cells. Front Mol Neurosci 10: 326.

Coste B, Mathur J, Schmidt M, Earley TJ, Ranade S, Petrus MJ, Dubin AE, Patapoutian A. 2010. Piezo1 and Piezo2 are essential components of distinct mechanically activated cation channels. Science 330: 55-60.

Coste B, Xiao B, Santos JS, Syeda R, Grandl J, Spencer KS, Kim SE, Schmidt M, Mathur J, Dubin AE, et al. 2012. Piezo proteins are pore-forming subunits of mechanically activated channels. Nature 483: 176-181.

Coste B, Murthy SE, Mathur J, Schmidt M, Mechioukhi Y, Delmas P, Patapoutian A. 2015. Piezo1 ion channel pore properties are dictated by C-terminal region. Nat Commun 6: 7223 .

Cunningham CL, Wu Z, Jafari A, Zhao B, Schrode K, Harkins-Perry S, Lauer A, Muller U. 2017. The murine catecholamine methyltransferase mTOMT is essential for mechanotransduction by cochlear hair cells. eLife 6: 24318.

Dallos P. 2008. Cochlear amplification, outer hair cells and prestin. Curr Opin Neurobiol 18: 370-376. 
Davenport EC, Pendolino V, Kontou G, McGee TP, Sheehan DF, Lopez-Domenech G, Farrant M, Kittler JT. 2017. An essential role for the tetraspanin LHFPL4 in the cell-typespecific targeting and clustering of synaptic GABAA receptors. Cell Rep 21: 70-83.

Delprat B, Michel V, Goodyear R, Yamasaki Y, Michalski N, El-Amraoui A, Perfettini I, Legrain P, Richardson G, Hardelin JP, et al. 2005. Myosin XVa and whirlin, two deafness gene products required for hair bundle growth, are located at the stereocilia tips and interact directly. Hum Mol Genet 14: 401-410.

Du X, Schwander M, Moresco EM, Viviani P, Haller C, Hildebrand MS, Pak K, Tarantino L, Roberts A, Richardson $\mathrm{H}$, et al. 2008. A catechol-O-methyltransferase that is essential for auditory function in mice and humans. Proc Natl Acad Sci 105: 14609-14614.

Effertz T, Becker L, Peng AW, Ricci AJ. 2017. Phosphoinositol-4,5-bisphosphate regulates auditory hair-cell mechanotransduction-channel pore properties and fast adaptation. J Neurosci 37: 11632-11646.

Erickson T, Morgan CP, Olt J, Hardy K, Busch-Nentwich E, Maeda R, Clemens R, Krey JF, Nechiporuk A, Barr-Gillespie PG, et al. 2017. Integration of Tmc1/2 into the mechanotransduction complex in zebrafish hair cells is regulated by transmembrane $O$-methyltransferase (Tomt). eLife 6: 28474.

Feske S, Gwack Y, Prakriya M, Srikanth S, Puppel SH, Tanasa B, Hogan PG, Lewis RS, Daly M, Rao A. 2006. A mutation in Orail causes immune deficiency by abrogating CRAC channel function. Nature 441: 179-185.

Fettiplace R. 2009. Defining features of the hair cell mechanoelectrical transducer channel. Pflugers Arch 458: 11151123.

Fettiplace R. 2016. Is TMC1 the hair cell mechanotransducer channel? Biophys J 111: 3-9.

Fettiplace R. 2017. Hair cell transduction, tuning, and synaptic transmission in the mammalian cochlea. Compr Physiol 7: 1197-1227.

Fettiplace R, Kim KX. 2014. The physiology of mechanoelectrical transduction channels in hearing. Physiol Rev 94: 951-986.

Geng R, Melki S, Chen DH, Tian G, Furness DN, OshimaTakago T, Neef J, Moser T, Askew C, Horwitz G, et al. 2012. The mechanosensory structure of the hair cell requires clarin-1, a protein encoded by Usher syndrome III causative gene. J Neurosci 32: 9485-9498.

Gentry HR, Singer AU, Betts L, Yang C, Ferrara JD, Sondek J, Parise LV. 2005. Structural and biochemical characterization of CIB1 delineates a new family of EF-hand-containing proteins. J Biol Chem 280: 8407-8415.

Gerka-Stuyt J, Au A, Peachey NS, Alagramam KN. 2013. Transient receptor potential melastatin 1: A hair cell transduction channel candidate. PLoS ONE 8: e77213.

Giese APJ, Tang YQ, Sinha GP, Bowl MR, Goldring AC, Parker A, Freeman MJ, Brown SDM, Riazuddin S, Fettiplace R, et al. 2017. CIB2 interacts with TMC1 and TMC2 and is essential for mechanotransduction in auditory hair cells. Nat Commun 8: 43.

Gillespie PG, Muller U. 2009. Mechanotransduction by hair cells: Models, molecules, and mechanisms. Cell 139: 33-44.
Gleason MR, Nagiel A, Jamet S, Vologodskaia M, LopezSchier H, Hudspeth AJ. 2009. The transmembrane inner ear (Tmie) protein is essential for normal hearing and balance in the zebrafish. Proc Natl Acad Sci 106: 2134721352.

Goldstein SA, Miller C. 1991. Site-specific mutations in a minimal voltage-dependent $\mathrm{K}^{+}$channel alter ion selectivity and open-channel block. Neuron 7: 403-408.

Goodyear RJ, Gale JE, Ranatunga KM, Kros CJ, Richardson GP. 2008. Aminoglycoside-induced phosphatidylserine externalization in sensory hair cells is regionally restricted, rapid, and reversible. J Neurosci 28: 9939-9952.

Grati M, Kachar B. 2011. Myosin VIIa and sans localization at stereocilia upper tip-link density implicates these Usher syndrome proteins in mechanotransduction. Proc Natl Acad Sci 108: 11476-11481.

Grillet N, Xiong W, Reynolds A, Kazmierczak P, Sato T, Lillo C, Dumont RA, Hintermann E, Sczaniecka A, Schwander $M$, et al. 2009. Harmonin mutations cause mechanotransduction defects in cochlear hair cells. Neuron 62: $375-$ 387.

Grimm C, Cuajungco MP, van Aken AF, Schnee M, Jors S, Kros CJ, Ricci AJ, Heller S. 2007. A helix-breaking mutation in TRPML3 leads to constitutive activity underlying deafness in the varitint-waddler mouse. Proc Natl Acad Sci 104: 19583-19588.

Guo Y, Wang Y, Zhang W, Meltzer S, Zanini D, Yu Y, Li J, Cheng T, Guo Z, Wang Q, et al. 2016. Transmembrane channel-like $(t m c)$ gene regulates Drosophila larval locomotion. Proc Natl Acad Sci 113: 7243-7248.

Hardie RC, Franze K. 2012. Photomechanical responses in Drosophila photoreceptors. Science 338: 260-263.

He DZ, Jia S, Dallos P. 2004. Mechanoelectrical transduction of adult outer hair cells studied in a gerbil hemicochlea. Nature 429: 766-770.

Hirono M, Denis CS, Richardson GP, Gillespie PG. 2004. Hair cells require phosphatidylinositol 4,5-bisphosphate for mechanical transduction and adaptation. Neuron 44: 309-320.

Holt JR, Gillespie SK, Provance DW, Shah K, Shokat KM, Corey DP, Mercer JA, Gillespie PG. 2002. A chemicalgenetic strategy implicates myosin-1c in adaptation by hair cells. Cell 108: 371-381.

Horwitz GC, Lelli A, Geleoc GS, Holt JR. 2010. HCN channels are not required for mechanotransduction in sensory hair cells of the mouse inner ear. PLOS ONE 5: e8627.

Jackson AC, Nicoll RA. 2011. The expanding social network of ionotropic glutamate receptors: TARPs and other transmembrane auxiliary subunits. Neuron 70: 178-199.

Jia S, Dallos P, He DZ. 2007. Mechanoelectric transduction of adult inner hair cells. J Neurosci 27: 1006-1014.

Jors S, Grimm C, Becker L, Heller S. 2010. Genetic inactivation of Trpml3 does not lead to hearing and vestibular impairment in mice. PLoS ONE 5: e14317.

Kalay E, Li Y, Uzumcu A, Uyguner O, Collin RW, Caylan R, Ulubil-Emiroglu M, Kersten FF, Hafiz G, Wijk EV, et al. 2006. Mutations in the lipoma HMGIC fusion partner-like 5 (LHFPL5) gene cause autosomal recessive nonsyndromic hearing loss. Hum Mutat 27: 633-639.

Kawashima Y, Geleoc GS, Kurima K, Labay V, Lelli A, Asai Y, Makishima T, Wu DK, Della Santina CC, Holt JR, et al. 
C.L. Cunningham and U. Müller

2011. Mechanotransduction in mouse inner ear hair cells requires transmembrane channel-like genes. J Clin Invest 121: $4796-4809$.

Kawashima Y, Kurima K, Pan B, Griffith AJ, Holt JR. 2015. Transmembrane channel-like (TMC) genes are required for auditory and vestibular mechanosensation. Pflugers Arch 467: 85-94.

Kazmierczak P, Sakaguchi H, Tokita J, Wilson-Kubalek EM, Milligan RA, Muller U, Kachar B. 2007. Cadherin 23 and protocadherin 15 interact to form tip-link filaments in sensory hair cells. Nature 449: 87-91.

Keresztes G, Mutai H, Heller S. 2003. TMC and EVER genes belong to a larger novel family, the TMC gene family encoding transmembrane proteins. BMC Genomics 4: 24

Kim KX, Fettiplace R. 2013. Developmental changes in the cochlear hair cell mechanotransducer channel and their regulation by transmembrane channel-like proteins. J Gen Physiol 141: 141-148.

Kim KX, Beurg M, Hackney CM, Furness DN, Mahendrasingam S, Fettiplace R. 2013. The role of transmembrane channel-like proteins in the operation of hair cell mechanotransducer channels. J Gen Physiol 142: 493-505.

Kros CJ, Marcotti W, van Netten SM, Self TJ, Libby RT, Brown SD, Richardson GP, Steel KP. 2002. Reduced climbing and increased slipping adaptation in cochlear hair cells of mice with Myo7a mutations. Nat Neurosci 5: 41-47.

Kurima K, Peters LM, Yang Y, Riazuddin S, Ahmed ZM, Naz S, Arnaud D, Drury S, Mo J, Makishima T, et al. 2002. Dominant and recessive deafness caused by mutations of a novel gene, TMC1, required for cochlear hair-cell function. Nat Genet 30: 277-284.

Kurima K, Yang Y, Sorber K, Griffith AJ. 2003. Characterization of the transmembrane channel-like (TMC) gene family: Functional clues from hearing loss and epidermodysplasia verruciformis. Genomics 82: 300-308.

Kurima K, Ebrahim S, Pan B, Sedlacek M, Sengupta P, Millis BA, Cui R, Nakanishi H, Fujikawa T, Kawashima Y, et al 2015. TMC1 and TMC2 localize at the site of mechanotransduction in mammalian inner ear hair cell stereocilia. Cell Rep 12: 1606-1617.

Kwan KY, Allchorne AJ, Vollrath MA, Christensen AP, Zhang DS, Woolf CJ, Corey DP. 2006. TRPA1 contributes to cold, mechanical, and chemical nociception but is not essential for hair-cell transduction. Neuron 50: 277-289.

Labay V, Weichert RM, Makishima T, Griffith AJ. 2010. Topology of transmembrane channel-like gene 1 protein. Biochemistry 49: 8592-8598.

Lai CC, Hong K, Kinnell M, Chalfie M, Driscoll M. 1996. Sequence and transmembrane topology of MEC- 4 , an ion channel subunit required for mechanotransduction in Caenorhabditis elegans. J Cell Biol 133: 1071-1081.

Lazarczyk M, Pons C, Mendoza JA, Cassonnet P, Jacob Y, Favre M. 2008. Regulation of cellular zinc balance as a potential mechanism of EVER-mediated protection against pathogenesis by cutaneous oncogenic human papillomaviruses. J Exp Med 205: 35-42.

Lelli A, Asai Y, Forge A, Holt JR, Geleoc GS. 2009. Tonotopic gradient in the developmental acquisition of sensory transduction in outer hair cells of the mouse cochlea. $J$ Neurophysiol 101: 2961-2973.
Letts VA, Felix R, Biddlecome GH, Arikkath J, Mahaffey CL, Valenzuela A, Bartlett FS II, Mori Y, Campbell KP, Frankel WN. 1998. The mouse stargazer gene encodes a neuronal $\mathrm{Ca}^{2+}$-channel $\gamma$ subunit. Nat Genet 19:340-347.

Liedtke W, Choe Y, Marti-Renom MA, Bell AM, Denis CS, Sali A, Hudspeth AJ, Friedman JM, Heller S. 2000. Vanilloid receptor-related osmotically activated channel (VR-OAC), a candidate vertebrate osmoreceptor. Cell 103: 525-535.

Long SB, Campbell EB, Mackinnon R. 2005. Crystal structure of a mammalian voltage-dependent Shaker family $\mathrm{K}^{+}$ channel. Science 309: 897-903.

Longo-Guess CM, Gagnon LH, Cook SA, Wu J, Zheng QY, Johnson KR. 2005. A missense mutation in the previously undescribed gene Tmhs underlies deafness in hurry-scurry (hscy) mice. Proc Natl Acad Sci 102: 7894-7899.

Maeda R, Kindt KS, Mo W, Morgan CP, Erickson T, Zhao H, Clemens-Grisham R, Barr-Gillespie PG, Nicolson T. 2014. Tip-link protein protocadherin 15 interacts with transmembrane channel-like proteins TMC1 and TMC2. Proc Natl Acad Sci 111: 12907-12912.

Mahendrasingam S, Fettiplace R, Alagramam KN, Cross E, Furness DN. 2017. Spatiotemporal changes in the distribution of LHFPL5 in mice cochlear hair bundles during development and in the absence of PCDH15. PLOS ONE 12: $\mathrm{e} 0185285$.

Manji SS, Miller KA, Williams LH, Dahl HH. 2012. Identification of three novel hearing loss mouse strains with mutations in the Tmcl gene. Am J Pathol 180: 1560-1569.

Mannisto PT, Kaakkola S. 1999. Catechol-O-methyltransferase (COMT): Biochemistry, molecular biology, pharmacology, and clinical efficacy of the new selective COMT inhibitors. Pharmacol Rev 51: 593-628.

Marcotti W, Erven A, Johnson SL, Steel KP, Kros CJ. 2006 Tmcl is necessary for normal functional maturation and survival of inner and outer hair cells in the mouse cochlea. J Physiol 574: 677-698.

McCrossan ZA, Abbott GW. 2004. The MinK-related peptides. Neuropharmacology 47: 787-821.

McNally BA, Somasundaram A, Yamashita M, Prakriya M. 2012. Gated regulation of CRAC channel ion selectivity by STIM1. Nature 482: 241-245.

Michalski N, Michel V, Caberlotto E, Lefevre GM, van Aken AF, Tinevez JY, Bizard E, Houbron C, Weil D, Hardelin JP, et al. 2009. Harmonin-b, an actin-binding scaffold protein, is involved in the adaptation of mechanoelectrical transduction by sensory hair cells. Pflugers Arch 459: 115-130.

Michel V, Booth KT, Patni P, Cortese M, Azaiez H, Bahloul A, Kahrizi K, Labbe M, Emptoz A, Lelli A, et al. 2017. CIB2, defective in isolated deafness, is key for auditory hair cell mechanotransduction and survival. EMBO Mol Med 9: 1711-1731.

Mitchem KL, Hibbard E, Beyer LA, Bosom K, Dootz GA, Dolan DF, Johnson KR, Raphael Y, Kohrman DC. 2002. Mutation of the novel gene Tmie results in sensory cell defects in the inner ear of spinner, a mouse model of human hearing loss DFNB6. Hum Mol Genet 11: 18871898.

Morgan CP, Zhao H, LeMasurier M, Xiong W, Pan B, Avenarius MR, Bateschell M, Larisch R, Ricci AJ, Mueller U, et al. 2017. TRPV5, TRPV6, TRPM6, and TRPM7 do not 
contribute to hair-cell mechanotransduction. bioRxiv doi: $10.1101 / 204172$.

Nagata K, Zheng L, Madathany T, Castiglioni AJ, Bartles JR, Garcia-Anoveros J. 2008. The varitint-waddler (Va) deafness mutation in TRPML3 generates constitutive, inward rectifying currents and causes cell degeneration. Proc Natl Acad Sci 105: 353-358.

Naz S, Giguere CM, Kohrman DC, Mitchem KL, Riazuddin S, Morell RJ, Ramesh A, Srisailpathy S, Deshmukh D, Riazuddin S, et al. 2002. Mutations in a novel gene, TMIE, are associated with hearing loss linked to the DFNB6 locus. Am J Hum Genet 71: 632-636.

O'Hagan R, Chalfie M, Goodman MB. 2005. The MEC-4 DEG/ENaC channel of Caenorhabditis elegans touch receptor neurons transduces mechanical signals. Nat Neurosci 8: 43-50.

Palmiter RD, Huang L. 2004. Efflux and compartmentalization of zinc by members of the SLC30 family of solute carriers. Pflugers Arch 447: 744-751.

Pan B, Geleoc GS, Asai Y, Horwitz GC, Kurima K, Ishikawa K, Kawashima Y, Griffith AJ, Holt JR. 2013. TMC1 and TMC2 are components of the mechanotransduction channel in hair cells of the mammalian inner ear. Neuron 79: 504-515.

Peng AW, Salles FT, Pan B, Ricci AJ. 2011. Integrating the biophysical and molecular mechanisms of auditory hair cell mechanotransduction. Nat Commun 2: 523.

Pickles JO, Comis SD, Osborne MP. 1984. Cross-links between stereocilia in the guinea pig organ of Corti, and their possible relation to sensory transduction. Hear Res 15: $103-112$.

Prakriya M, Feske S, Gwack Y, Srikanth S, Rao A, Hogan PG. 2006. Orail is an essential pore subunit of the CRAC channel. Nature 443: 230-233.

Qiu Z, Dubin AE, Mathur J, Tu B, Reddy K, Miraglia LJ, Reinhardt J, Orth AP, Patapoutian A. 2014. SWELL1, a plasma membrane protein, is an essential component of volume-regulated anion channel. Cell 157: 447-458.

Quick K, Zhao J, Eijkelkamp N, Linley JE, Rugiero F, Cox JJ, Raouf R, Gringhuis M, Sexton JE, Abramowitz J, et al. 2012. TRPC3 and TRPC6 are essential for normal mechanotransduction in subsets of sensory neurons and cochlear hair cells. Open Biol 2: 120068.

Ramakrishnan NA, Drescher MJ, Barretto RL, Beisel KW, Hatfield JS, Drescher DG. 2009. Calcium-dependent binding of $\mathrm{HCN} 1$ channel protein to hair cell stereociliary tip link protein protocadherin 15 CD3. J Biol Chem 284: 3227-3238.

Ramoz N, Rueda LA, Bouadjar B, Montoya LS, Orth G, Favre M. 2002. Mutations in two adjacent novel genes are associated with epidermodysplasia verruciformis. Nat Genet 32: $579-581$

Ranade SS, Syeda R, Patapoutian A. 2015. Mechanically activated ion channels. Neuron 87: 1162-1179.

Riazuddin S, Belyantseva IA, Giese AP, Lee K, Indzhykulian AA, Nandamuri SP, Yousaf R, Sinha GP, Lee S, Terrell D, et al. 2012. Alterations of the CIB2 calcium- and integrinbinding protein cause Usher syndrome type $1 \mathrm{~J}$ and nonsyndromic deafness DFNB48. Nat Genet 44: 1265-1271.
Ricci AJ, Crawford AC, Fettiplace R. 2003. Tonotopic variation in the conductance of the hair cell mechanotransducer channel. Neuron 40: 983-990.

Scheffer DI, Shen J, Corey DP, Chen ZY. 2015. Gene expression by mouse inner ear hair cells during development. $J$ Neurosci 35: 6366-6380.

Schwander M, Kachar B, Muller U. 2010. Review series: The cell biology of hearing. J Cell Biol 190: 9-20.

Shabbir MI, Ahmed ZM, Khan SY, Riazuddin S, Waryah AM, Khan SN, Camps RD, Ghosh M, Kabra M, Belyantseva IA, et al. 2006. Mutations of human TMHS cause recessively inherited non-syndromic hearing loss. J Med Genet 43: 634-640.

Shin JB, Adams D, Paukert M, Siba M, Sidi S, Levin M, Gillespie PG, Grunder S. 2005. Xenopus TRPN1 (NOMPC) localizes to microtubule-based cilia in epithelial cells, including inner-ear hair cells. Proc Natl Acad Sci 102: 12572-12577.

Sidi S, Friedrich RW, Nicolson T. 2003. NompC TRP channel required for vertebrate sensory hair cell mechanotransduction. Science 301: 96-99.

Siemens J, Lillo C, Dumont RA, Reynolds A, Williams DS, Gillespie PG, Muller U. 2004. Cadherin 23 is a component of the tip link in hair-cell stereocilia. Nature 428: 950955.

Sirianant L, Ousingsawat J, Tian Y, Schreiber R, Kunzelmann K. 2014. TMC8 (EVER2) attenuates intracellular signaling by $\mathrm{Zn}^{2+}$ and $\mathrm{Ca}^{2+}$ and suppresses activation of $\mathrm{Cl}^{-}$currents. Cell Signal 26: 2826-2833.

Sollner C, Rauch GJ, Siemens J, Geisler R, Schuster SC, Muller U, Nicolson T, Tubingen Screen C. 2004. Mutations in cadherin 23 affect tip links in zebrafish sensory hair cells. Nature 428: 955-959.

Steigelman KA, Lelli A, Wu X, Gao J, Lin S, Piontek K, Wodarczyk C, Boletta A, Kim H, Qian F, et al. 2011. Polycystin-1 is required for stereocilia structure but not for mechanotransduction in inner ear hair cells. J Neurosci 31: 12241-12250.

Stepanyan R, Frolenkov GI. 2009. Fast adaptation and $\mathrm{Ca}^{2+}$ sensitivity of the mechanotransducer require myosinXVa in inner but not outer cochlear hair cells. J Neurosci 29: 4023-4034.

Syeda R, Qiu Z, Dubin AE, Murthy SE, Florendo MN, Mason DE, Mathur J, Cahalan SM, Peters EC, Montal M, et al. 2016. LRRC8 proteins form volume-regulated anion channels that sense ionic strength. Cell 164: 499-511.

Twomey EC, Yelshanskaya MV, Grassucci RA, Frank J, Sobolevsky AI. 2016. Elucidation of AMPA receptor-stargazin complexes by cryo-electron microscopy. Science 353: 83-86.

van Aken AF, Atiba-Davies M, Marcotti W, Goodyear RJ, Bryant JE, Richardson GP, Noben-Trauth K, Kros CJ 2008. TRPML3 mutations cause impaired mechano-electrical transduction and depolarization by an inwardrectifier cation current in auditory hair cells of varitintwaddler mice. J Physiol 586: 5403-5418.

Vannier B, Zhu X, Brown D, Birnbaumer L. 1998. The membrane topology of human transient receptor potential 3 as inferred from glycosylation-scanning mutagenesis and epitope immunocytochemistry. J Biol Chem 273: 86758679. 
C.L. Cunningham and U. Müller

Vig M, Peinelt C, Beck A, Koomoa DL, Rabah D, KoblanHuberson M, Kraft S, Turner H, Fleig A, Penner R, et al. 2006. CRACM1 is a plasma membrane protein essential for store-operated $\mathrm{Ca}^{2+}$ entry. Science 312: 1220-1223.

Voss FK, Ullrich F, Munch J, Lazarow K, Lutter D, Mah N, Andrade-Navarro MA, von Kries JP, Stauber T, Jentsch TJ. 2014. Identification of LRRC8 heteromers as an essential component of the volume-regulated anion channel VRAC. Science 344: 634-638.

Vreugde S, Erven A, Kros CJ, Marcotti W, Fuchs H, Kurima K, Wilcox ER, Friedman TB, Griffith AJ, Balling R, et al. 2002. Beethoven, a mouse model for dominant, progressive hearing loss DFNA36. Nat Genet 30: 257-258.

Waguespack J, Salles FT, Kachar B, Ricci AJ. 2007. Stepwise morphological and functional maturation of mechanotransduction in rat outer hair cells. J Neurosci 27: 13890-13902.

Wang X, Li G, Liu J, Liu J, Xu XZ. 2016. TMC-1 mediates alkaline sensation in $C$. elegans through nociceptive neurons. Neuron 91: 146-154.

Wang Y, Li J, Yao X, Li W, Du H, Tang M, Xiong W, Chai R, $\mathrm{Xu}$ Z. 2017. Loss of CIB2 causes profound hearing loss and abolishes mechanoelectrical transduction in mice. Front Mol Neurosci 10: 401.

Wu X, Indzhykulian AA, Niksch PD, Webber RM, Garcia-Gonzalez M, Watnick T, Zhou J, Vollrath MA, Corey DP. 2016. Hair-cell mechanotransduction persists in TRP channel knockout mice. PLoS ONE 11: e0155577.

Wu Z, Grillet N, Zhao B, Cunningham C, Harkins-Perry S, Coste B, Ranade S, Zebarjadi N, Beurg M, Fettiplace R, et al. 2017. Mechanosensory hair cells express two molecularly distinct mechanotransduction channels. Nat Neurosci 20: 24-33.

Xiong W, Grillet N, Elledge HM, Wagner TF, Zhao B, Johnson KR, Kazmierczak P, Muller U. 2012. TMHS is an integral component of the mechanotransduction machinery of cochlear hair cells. Cell 151: 1283-1295.

Yamasaki T, Hoyos-Ramirez E, Martenson JS, MorimotoTomita M, Tomita S. 2017. GARLH family proteins stabilize GABAA receptors at synapses. Neuron 93: 11381152.e6.

Yan Z, Zhang W, He Y, Gorczyca D, Xiang Y, Cheng LE, Meltzer S, Jan LY, Jan YN. 2013. Drosophila NOMPC is a mechanotransduction channel subunit for gentle-touch sensation. Nature 493: 221-225.

Yool AJ, Schwarz TL. 1991. Alteration of ionic selectivity of a $\mathrm{K}^{+}$channel by mutation of the $\mathrm{H} 5$ region. Nature 349 : 700-704.

Yue X, Zhao J, Li X, Fan Y, Duan D, Zhang X, Zou W, Sheng Y, Zhang T, Yang Q, et al. 2018. TMC proteins modulate egg laying and membrane excitability through a background leak conductance in C. elegans. Neuron 97: 1-15.

Zhang Q, Zhou P, Chen Z, Li M, Jiang H, Gao Z, Yang H. 2013. Dynamic PIP2 interactions with voltage sensor elements contribute to KCNQ2 channel gating. Proc Natl Acad Sci 110: 20093-20098.

Zhang L, Gualberto DG, Guo X, Correa P, Jee C, Garcia LR. 2015. TMC-1 attenuates C. elegans development and sexual behaviour in a chemically defined food environment. Nat Commun 6: 6345.

Zhang YV, Aikin TJ, Li Z, Montell C. 2016. The basis of food texture sensation in Drosophila. Neuron 91: 863-877.

Zhao B, Wu Z, Grillet N, Yan L, Xiong W, Harkins-Perry S, Muller U. 2014. TMIE is an essential component of the mechanotransduction machinery of cochlear hair cells. Neuron 84: 954-967.

Zhao Q, Wu K, Geng J, Chi S, Wang Y, Zhi P, Zhang M, Xiao B. 2016. Ion permeation and mechanotransduction mechanisms of mechanosensitive piezo channels. Neuron 89: $1248-1263$. 


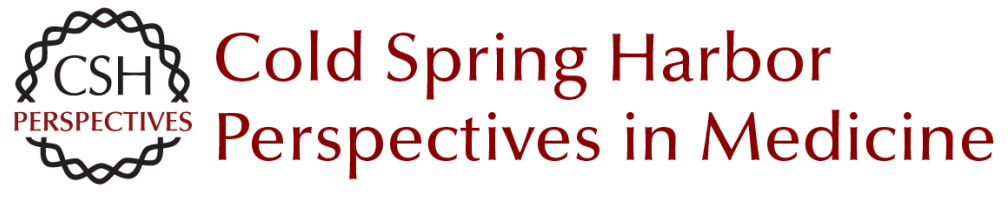

\section{Molecular Structure of the Hair Cell Mechanoelectrical Transduction Complex}

Christopher L. Cunningham and Ulrich Müller

Cold Spring Harb Perspect Med 2019; doi: 10.1101/cshperspect.a033167 originally published online August 6, 2018

Subject Collection Function and Dysfunction of the Cochlea

Hidden Hearing Loss: A Disorder with Multiple

Etiologies and Mechanisms

David C. Kohrman, Guoqiang Wan, Luis Cassinotti, et al.

Hair Cell Afferent Synapses: Function and

Dysfunction

Stuart L. Johnson, Saaid Safieddine, Mirna Mustapha, et al.

Active Biomechanics of Sensory Hair Bundles Dolores Bozovic

The Tectorial Membrane: Mechanical Properties and Functions Jonathan B. Sellon, Roozbeh Ghaffari and Dennis M. Freeman

The Epidemiology of Deafness Abraham M. Sheffield and Richard J.H. Smith

Toward the Optical Cochlear Implant Tobias Dombrowski, Vladan Rankovic and Tobias Moser

Outer Hair Cells and Electromotility Jonathan Ashmore

Interactions between Macrophages and the Sensory Cells of the Inner Ear Mark E. Warchol
Development and Patterning of the Cochlea: From

Convergent Extension to Planar Polarity Mireille Montcouquiol and Matthew W. Kelley

Hair-Bundle Links: Genetics as the Gateway to Function Guy P. Richardson and Christine Petit

Aminoglycoside- and Cisplatin-Induced Ototoxicity: Mechanisms and Otoprotective Strategies

Corné J. Kros and Peter S. Steyger

Function and Dysfunction of TMC Channels in Inner Ear Hair Cells

David P. Corey, Nurunisa Akyuz and Jeffrey R. Holt

Cochlear Gene Therapy

Lawrence Lustig and Omar Akil

Age-Related Hearing Loss

Michael R. Bowl and Sally J. Dawson

Inner Ear Connexin Channels: Roles in Development and Maintenance of Cochlear

Function

Fabio Mammano

A Functional Perspective on the Evolution of the Cochlea Christine Köppl and Geoffrey A. Manley

For additional articles in this collection, see http://perspectivesinmedicine.cshlp.org/cgi/collection/ 